\title{
Improvement of fluconazole flowability and its effect on dissolution from tablets and capsules
}

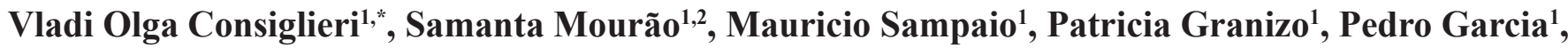 \\ Valeska Martinello', Rodrigo Spricigo ${ }^{1}$, Humberto Gomes Ferraz ${ }^{1}$
}

\author{
${ }^{1}$ Pharmacy Department, Faculty of Pharmaceutical Sciences, University of São Paulo, ${ }^{2}$ Faculty of Pharmacy, \\ University of Vale do Itajai
}

\begin{abstract}
The aim of this work was to improve fluconazole flowability by wet granulation and to study the effect of granulation on drug dissolution from tablets and capsules. Fluconazole was submitted to a process of wet granulation in a high-speed granulator using Plasdone K29/32 or K90. Flow properties of granules and dissolution profiles for tablets and capsules produced with them were determined. Fluconazole granules demonstrated better flowability, calculated by angle of repose and compressibility index data, compared with powder. Additionally, it was observed that the granulation process improved the dissolution efficiency (ED) of fluconazole from tablets and capsules, which could also suggest an increase in bioavailability. Higher dissolution efficiencies were achieved with Plasdone ${ }^{\circledR}$ K29/32.
\end{abstract}

Uniterms: Fluconazole/flowability. Tablets/dissolution. Capsules/dissolution. Plasdone

O objetivo deste trabalho foi melhorar as características de fluxo do fluconazol com o emprego da granulação úmida e estudar o efeito desse processo na dissolução do fármaco em cápsulas e comprimidos. O fluconazol foi submetido ao processo de granulação úmida num granulador de alta velocidade empregando Plasdone K29/32 e K90. Foram determinadas as propriedades de fluxo dos grânulos e obtidos os perfis de dissolução de cápsulas e comprimidos obtidos com os granulados em estudo. Os grânulos de fluconazol apresentaram melhores características de fluxo após o processamento, demonstradas por meio das determinações do ângulo de repouso e do índice de compressibilidade, comparativamente à matéria-prima. Adicionalmente, observou-se que o processo de granulação melhorou a eficiência de dissolução (ED) do fluconazol nos comprimidos e cápsulas.

Unitermos: Fluconazol/capacidade de fluxo. Comprimidos/dissolução. Cápsulas/dissolução. Plasdone .

\section{INTRODUCTION}

Fluconazole is a broad-spectrum antifungal agent, active by both oral and intravenous routes, for the treatment of superficial and systemic infections (Richardson et al., 1990). FCZ is a triazole that has established an exceptional therapeutic record for Candida infections including oropharyngeal and esophageal candidiasis, vulvovaginal candidiasis, candidemia and disseminated candidiasis (Cha, Sobel, 2004).

This drug presents a reasonable solubility and is more hydrophilic than other azole derivatives used as

*Correspondence: V. O. Consiglieri. Departamento de Farmácia, Faculdade de Ciências Farmacêuticas, Universidade de São Paulo. Av. Prof. Lineu Prestes, 580 - 05508-900 - São Paulo - SP, Brazil. E-mail: siglieri@usp.br antifungals where this leads to better absorption from the gastrointestinal tract (Kowalsky, Dixon, 1991). Porta, Chang, Storpirtis, (2005) and Pereira et al., (2004) have evaluated the bioavailability and bioequivalence of commercial capsule formulations of fluconazole available on the Brazilian market. In both studies, the commercial capsules were considered bioequivalent to the reference product.

FCZ presents very poor flowability yet there are no studies in the literature about this characteristic. Regarding the manufacturability of tablets, good flowability of the blend, i.e. the mixture of excipients and drug, is critical for compression in terms of dissolution, friability and content uniformity (Martinello et al., 2006). One way to improve the flowability of drugs and to make tablet production feasible is by using the wet granulation process. Granu- 
lation in a high shear mixer is a common method used in the production of granules. The main reasons for this are that high shear granulation produces spherical and wellcompacted granules in a relatively short time and that the equipment is of relatively simple construction and easily cleaned (Albertini et al., 2003).

There are many excipients that can be used as binder agents. Amongst them, cellulose derivatives, starch paste and PVP are the most usually applied (Lachman, Lieberman, Kanig, 2001). Wet granulation with binders can improve the flowability of the drug but can also affect its dissolution behavior. Except for bioequivalence studies, there is a lack of studies evaluating the effect of excipients in fluconazole dissolution from tablets. Studying the suppository form, Nair and Barghava (1999) evaluated the dissolution of fluconazole from hydrophilic, lipophilic, and amphiphilic bases. Additionally, the drug is only commercially available in Brazil as capsules in an oral dosage form.

For this reason, the aim of the present work was to produce granules of fluconazole with improved flowability, and to evaluate the effect of this process on the drug dissolution from tablets and capsules. Granules were prepared by wet granulation in a high shear mixer using PVP with different viscosities.

\section{MATERIAL AND METHODS}

\section{Material}

Fluconazole (SP Farma, FLP 0040102, India), Polyvinylpyrrolidone (Plasdone ${ }^{\circledR}$ K29/32 and K90/D, International Specialty Products, USA), Microcrystalline cellulose (Microcel ${ }^{\circledR}$ MC-101, Blanver, USA), Sodium Croscarmellose (Explocel ${ }^{\circledR}$, Blanver, USA), Magnesium stearate (Natural Pharma, Brazil) were all of pharmaceutical grade. Hydrochloric acid (HCl 37\% Merck, USA) and other reagents were of analytical grade. Fluconazole ( $>99 \%$ ) was used as standard in quantitative determinations.

\section{Granulation process}

FCZ was submitted to a process of wet granulation in a high-speed granulator (Diosna High Shear Granulation. Dierks \& Söhne $\mathrm{GmbH}$ ) under the following operating conditions: initial and final speed of the chopper were 350 and $500 \mathrm{rpm}$, respectively; initial and final speed of the impeller were 500 and $700 \mathrm{rpm}$, respectively. A solution of $20 \%$ Plasdone ${ }^{\circledR}$ K29/32 or $10 \%$ Plasdone ${ }^{\circledR}$ K90 was employed as the binder agent. Both granulates (FCZPK30 and FCZPK90, with PVP K30 and PVP K90, respectively) were selected in a conical screen cone mill (Quadro Comil-
I Square Engineering Inc., I Model U3-005, WaterlooCanada) with a sieve of $4.0 \mathrm{~mm}$. Granules were led into a fluid bed dryer (Diosna Minilab Fluid Bed Dryer) with operating temperatures of $99^{\circ} \mathrm{C}$ for the entrance air and $60{ }^{\circ} \mathrm{C}$ for the exit air, until a loss on drying value of less than $5 \%$ was obtained. Granules were then sieved through a $1.4-1.5 \mathrm{~mm}$ mesh.

\section{Flowability studies and assay of FCZ in granules}

The flow speed was observed by the drainage time of $100 \mathrm{~g}$ of fluconazole and of fluconazole granules through a perforated disk measuring $10.0 \mathrm{~mm}$ in diameter, in an Erweka GT Flow Analyser. The angle of repose and the flow were calculated by the equipment.

For the determination of bulk and tap densities, a volume of approximately $50 \mathrm{~mL}$ of fluconazole (FCZ) and fluconazole granules (FCZ K30 and FCZ K90) was individually transferred to a $100 \mathrm{~mL}$ test tube. The volume was then read directly to calculate the bulk density $\left(\rho_{\text {bulk }}\right)$ according to the mass/volume ratio. For tap density $\left(\rho_{\text {tap }}\right)$, the test tube was tapped about 3000 times, until volume was constant, using a Logan TAP-2 tap density analyzer. Compressibility was calculated using the equation (Lachman, Lieberman, Kanig, 2001):

$$
\% \text { compressibility }=\frac{\left(\rho_{\text {tap }}-\rho_{\text {bulk }}\right)}{\rho_{\text {tap }}} \times 100
$$

EQUATION 1 - Percent compressibility (\%); bulk density, $\rho_{\text {bulk }}$ $(\mathrm{g} / \mathrm{mL})$; tap density, $\rho_{\text {tap }}(\mathrm{g} / \mathrm{mL})$.

The amount of fluconazole in granules was spectrophotometrically determined at $260 \mathrm{~nm}$ (Bechmam Coulter, DU640) in water, using the analytical curve $\left(r^{2}=0.9974\right)$ from an in house pre-validated method (Equation 2).

$$
y=0.0021 x+0.0012
$$

EQUATION 2 - Analytical curve of the validated spectrophotometric method, at $260 \mathrm{~nm}$, in water (data not shown).

\section{Preparation of the formulations as capsules or tablets}

Tablets were produced in a $10 \mathrm{~mm}$ single-punch tablet press (Fabbe), with a compression force of 3000 $\mathrm{kg}$, after mixing powders and fluconazole granules in an Apex-Multipex biconical mixer. Capsules $\left(n^{\circ} 1\right)$ with the same compositions were prepared by manual filling. The compositions of capsules and tablets are shown in Table I. 
TABLE I - Compositions of capsules and tablets produced with fluconazole (FCZ), and fluconazole granules (FCZ K30 and FCZ K90).

\begin{tabular}{|c|c|c|c|c|}
\hline Formulation & Fluconazole & Magnesium stearate & Croscamelose & $\begin{array}{l}\text { Microcrystalline } \\
\text { cellulose }\end{array}$ \\
\hline \multicolumn{5}{|c|}{ Capsule composition (\%) } \\
\hline FCZ & 42.86 & 1.00 & 1.50 & 54.64 \\
\hline FCZ K30 & 47.46 & 1.00 & 1.50 & 50.04 \\
\hline FCZ K90 & 45.30 & 1.00 & 1.50 & 52.20 \\
\hline \multicolumn{5}{|c|}{ Tablet composition $(\%)$} \\
\hline FCZ & 42.86 & 1.00 & 3.00 & 53.14 \\
\hline FCZ K30 & 47.46 & 1.00 & 3.00 & 48.54 \\
\hline FCZ K90 & 45.30 & 1.00 & 3.00 & 50.70 \\
\hline
\end{tabular}

The average weight was obtained over 20 units, according to United States Pharmacopoeia (2008) and Farmacopéia Brasileira (1988) methods. The coefficients of variation (CV) were calculated. For each formulation, the friability was evaluated over a sample of 20 tablets. According to official specifications, hardness could not be less than $5 \mathrm{Kgf}$, and for friability, the acceptance criterion was a maximum loss of $1.5 \%$ of the initial weight (Farmacopéia Brasileira, 1988).

\section{Dissolution test}

The dissolution tests were accomplished in a dissolution tester (Logan instruments corp., I Model D-800) applying the following conditions (Porta, Chang, Storpirtis, 2005): apparatus 1 (basket), speed of $75 \mathrm{rpm}, 900 \mathrm{~mL}$ of $0.01 \mathrm{~N} \mathrm{HCl}$ solution at $37 \pm 0.5^{\circ} \mathrm{C}$. The filtered aliquots of 10 $\mathrm{mL}$ were removed from each vessel at $5,10,15,20,25$ and 30 minutes, with immediate replacement of fresh medium. The percentages of drug dissolved were determined by recording each sample in a spectrophotometer at $260 \mathrm{~nm}$, and dissolution profiles of FCZ during the test were obtained.

The dissolution efficiencies (DE\%) were determined for the ratio among the area under the dissolution curves, between the times zero and 30 minutes $\left(\mathrm{ASC}_{0-30}\right)$ calculated applying the trapezoidal method, and the total area of the rectangle $\left(\mathrm{ASC}_{\mathrm{TR}}\right)$ defined for the ordinate ( $100 \%$ of dissolution $)$ and for the abscissa ( $\mathrm{t}=30$ minutes $)$ (Khan, Rhodes, 1975). Dissolution efficiency values were submitted to analysis of variance (ANOVA) to evaluate significant differences among the dissolution profiles.

\section{RESULTS AND DISCUSSION}

\section{Fluconazole granules and flowability studies}

Among the many particles properties required in the production of solid dosage form, flowability is essential to ensure a successful tabletting process. Powder flowability is influenced by many factors such as particle size, size distribution, shape, surface texture, surface energy, chemical composition, moisture content, vessel geometry and other factors. A common and easy method widely employed in the pharmaceutical industry for flowability measurement is the tapping test (Li et al., 2004; Nokhodchi et al., 2007).

According to Zatloukal and Sklubalová (2007), in order to evaluate the flow rate of a layer of material flowing uniformly from the outlet of a cylindrical hopper, the relationship to the bulk density of the powder is more useful than the tapped density which represents the properties of the stagnant layer of non-flowing material at the periphery of the hopper.

The flowability was evaluated for fluconazole and granules by the angle of repose, percentage compressibility and also by direct determination of the flow through a 10 $\mathrm{mm}$ diameter hole. Bulk and tap densities of powder and granules were used to calculate the compressibility index (\%). The flowability data are shown in Table II. The compressibility and angle of repose were indirect measures of the flow and lower values for these parameters indicate better flowability.

The production of granules of fluconazole with PVP (Plasdone ${ }^{\circledR}$ K29/32 and Plasdone ${ }^{\circledR}$ K90) improved

TABLE II - Flowability characteristics of fluconazole (FCZ) and fluconazole granules produced with Plasdone ${ }^{\circledR}$ K29/32 (FCZ K30) or Plasdone ${ }^{\circledR}$ K90/D (FCZ K90). N=3

\begin{tabular}{lccc}
\hline & Flow $(\mathrm{g} / \mathrm{s})$ & $\begin{array}{c}\text { Angle of } \\
\text { repose }(\alpha)\end{array}$ & $\begin{array}{c}\text { Compressibility } \\
(\%)\end{array}$ \\
\hline FCZ & nd & nd & 38.78 \\
FCZ K30 & 12.10 & 39.8 & 11.54 \\
FCZ K90 & 13.29 & 39.9 & 12.96 \\
\hline
\end{tabular}

$\mathrm{nd}=$ not determined 
angle of repose, flow and compressibility of fluconazole. No significant difference between the two binder agents was observed based on these characteristics. However, different amounts of binder agents were used to produce granules: about 10\% PVP K29/32 and approximately 5\% PVP K90. Therefore, as expected, Plasdone K90 presented a more efficient binder capacity than K29/32, because of its viscosity.

Wan et al. (1996), using PVP K29/32 and K90 as binder agents in the production of propranolol granules, observed that PVP of higher molecular weight such as Plasdone ${ }^{\circledR}$ K90, provided stronger bonds to the granules and thus enabled them to better withstand the effects of attritive forces generated during fluidized bed granulation.

The amount of fluconazole was determined in the granules by an in-house validated spectrophotometric procedure using the equation obtained by the analytical curve. Granules produced with Plasdone ${ }^{\circledR}$ K29/32 (FCZ $\mathrm{K} 30$ ) presented $90.26 \% \mathrm{FCZ}$, and the content of fluconazole in granules produced with Plasdone ${ }^{\circledR} \mathrm{K} 90$ (FCZ K90) was $94.62 \%$.

\section{Dosage forms and dissolution studies}

Capsules and tablets were prepared taking into account the fluconazole content in the granules. The average weight, hardness, and friability of tablets were obtained according to USP 31 ed. (2008) and Farmacopéia Brasileira (1988) as shown in Tables III and IV.

The friability of tablets met the requirements (no greater than $1.5 \%$ mass loss). The values for hardness and average weight of the tablets obtained for the fluconazole and granules were also within the requirements. However, the coefficient of variation (CV) of FCZ tablets was very high, while values obtained for the fluconazole granules
TABLE IV - Hardness and friability data of tablets produced with fluconazole (FCZ) and granules (FCZ K30 and FCZ K90). N=20

\begin{tabular}{lcc}
\hline Tablets & Hardness (Kgf) & Friability (\%) \\
\hline FCZ & $7.10(87.1)$ & 0.39 \\
FCZ K30 & $6.41(10.2)$ & 0.20 \\
FCZ K90 & $6.50(9.3)$ & 0.16 \\
\hline
\end{tabular}

Coefficients of variations (\%) are between parentheses.

TABLE III - Average weight data of capsules and tablets produced with fluconazole (FCZ) and granules (FCZ K30 and FCZ K90). $\mathrm{N}=20$

\begin{tabular}{lll}
\hline & Formulation & Weight $(\mathrm{g})$ \\
\hline Capsules & FCZ & $0.352(1.3)$ \\
& FCZ K30 & $0.389(1.4)$ \\
Tablets & FCZ K90 & $0.375(2.4)$ \\
& FCZ & $0.318(5.3)$ \\
& FCZ K30 & $0.305(1.2)$ \\
& FCZ K90 & $0.295(1.2)$ \\
\hline
\end{tabular}

Coefficients of variations (\%) are between parentheses.

were lower. This indicates that besides poor flowability, which led to uniform filling of the matrix, fluconazole presented reduced compressing capability.

Dissolution profiles of FCZ from capsules and tablets produced with FCZ and FCZ granules (FCZ K30 and FCZ K90) were obtained according to Porta, Chang, Storpirtis (2005). The drug concentrations of each sample were determined by spectrophotometry at $260 \mathrm{~nm}$ and the percentages of FCZ dissolved are shown in Table V.

The dissolution efficiencies (DE) were calculated from zero to 30 minutes (ASC 0-30), and these results

TABLE V - Percentages of drug dissolved for capsules and tablets produced with fluconazole (FCZ) and granules (FCZ K30 and FCZ K90). N=4

\begin{tabular}{lcccccc}
\hline \multirow{2}{*}{ Time (min) } & \multicolumn{7}{c}{ \% fluconazole dissolved } \\
\cline { 2 - 7 } & \multicolumn{7}{c}{ Capsules } & \multicolumn{3}{c}{ Tablets } \\
\cline { 2 - 6 } & $7.3(21.9)$ & $44.4(6.4)$ & $46.8(2.4)$ & $4.3(19.3)$ & $55.2(9.6)$ & $41.4(13.3)$ \\
\hline 5 & $17.7(19.1)$ & $69.1(5.0)$ & $64.8(1.1)$ & $10.6(11.6)$ & $72.5(8.5)$ & $60.7(6.9)$ \\
10 & $23.2(18.3)$ & $89.9(2.6)$ & $72.9(3.3)$ & $13.5(8.0)$ & $86.4(7.5)$ & $73.8(4.9)$ \\
15 & $32.6(24.0)$ & $94.2(1.9)$ & $77.4(4.1)$ & $16.7(5.3)$ & $91.1(2.9)$ & $84.2(9.4)$ \\
20 & $40.7(26.3)$ & $96.4(1.6)$ & $78.7(4.1)$ & $19.4(4.3)$ & $92.3(2.6)$ & $85.9(2.8)$ \\
25 & $46.7(24.0)$ & $97.3(2.2)$ & $79.0(4.5)$ & $22.4(3.9)$ & $93.0(2.1)$ & $87.5(2.2)$ \\
30 &
\end{tabular}

Coefficients of variations ( $\%)$ are between parentheses. 
were submitted to analysis of variance (ANOVA) which expressed significant differences among them (Table VI).

TABLE VI - Dissolution efficiency of fluconazole from capsules and tablets produced with $\mathrm{FCZ}$ and granules (FCZ K30 and FCZ K90). $\mathrm{N}=4$

\begin{tabular}{lcc}
\hline Formulation & \multicolumn{2}{c}{ Dissolution efficiency (\%) } \\
\cline { 2 - 3 } & Capsules & Tablets \\
\hline FCZ & $34.33(26.7)$ & $12.61(4.7)$ \\
FCZ K30 & $74.24(1.9)$ & $73.99(4.4)$ \\
FCZ K90 & $63.35(3.9)$ & $64.96(7.0)$ \\
\hline
\end{tabular}

Coefficients of variation (\%) are between parentheses.

The dissolution profiles of the drug are summarized in Figures 1 and 2. The releases of fluconazol from tablets produced with the granules (FCZ P30 and FCZ P90) were much faster than releases from tablets produced with FCZ. Similar results were found for capsules. All tablets and capsules disintegrated rapidly at the beginning of the dissolution process, offering more surface area available for dissolution. More than $60 \%$ of the drug was released within 10 min for all formulations produced with granules, in contrast to those obtained with FCZ, which released only $17.7 \%$ (capsules) and $10.6 \%$ (tablets). Dissolution efficiency data (Table VI) shows that capsules and tablets produced with FCZ presented similar dissolution behavior to that of an extended-release formulation. This finding is in accordance with the studies of Orelli and Leuenberger (2004) who found similar results in a study on release from tablets produced with granules of proquazone. These authors considered this dissolution behavior a characteristic of poorly wettable drugs. Therefore, fluconazole can be characterized as a poorly wettable drug and consequently, the increased dissolution rate seen in the granule form can be explained by the higher wettability achieved by the addition of the hydrophilic excipient.

Greater improvement in dissolution efficiency was observed when PVP K29/32 was used. Similar results were observed by Albertini et al. (2003) in piroxicam granules or physical mixtures with PVP K12 and PVP K90, where the improvement of dissolution was more significant with the use of PVP of lesser molecular weight. This could be explained by the higher viscosity of PVP K90 leading to stronger bonds in granules. Additionally, the drug probably had to pass through a more viscous layer to be released, when PVP K90 was used.

No studies were available on the flowability properties of fluconazole, but the results from flow, angle of repose and compressibility clearly indicated that direct

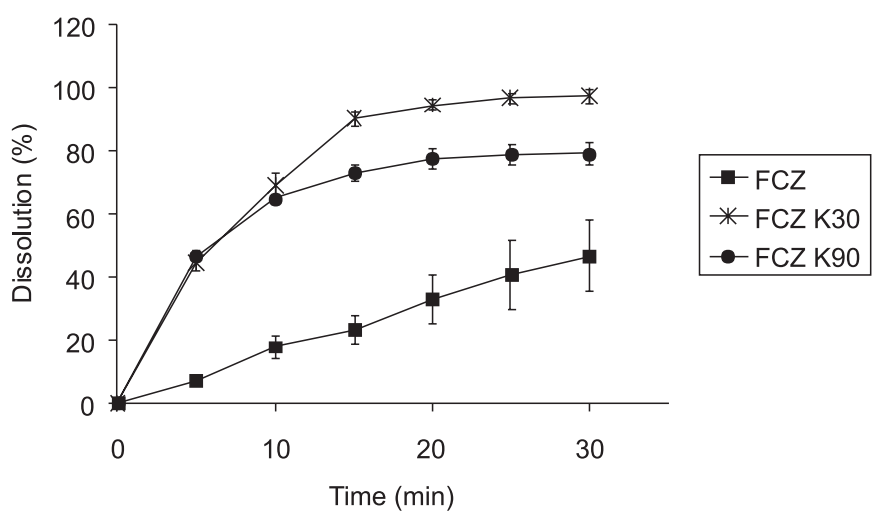

FIGURE 1 - Drug dissolution profile from capsules with fluconazole (FCZ) and fluconazole granules (FCZ K30 and FCZ K 90).

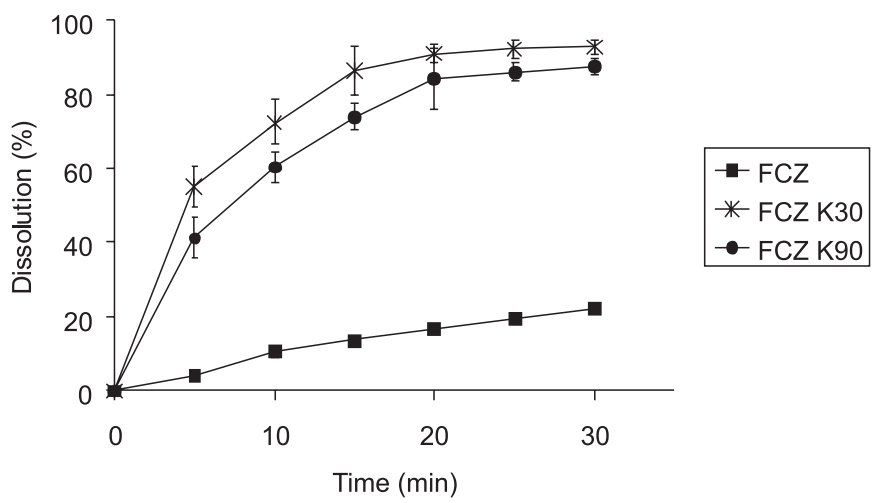

FIGURE 2 - Drug dissolution profile of tablets produced with fluconazole (FCZ) and granules (FCZ K30 and FCZ K90).

compression is not possible with this drug. The powder did not flow through the hole in the equipment and repose angle and flow were not determined. Taking into account that direct compression presents many advantages over other techniques, especially by decreasing the number of stages in the manufacturing process, it would be advantageous to use pre co-processed powder containing a large amount of drug for direct compression.

In conclusion, under these experimental conditions, the fluconazole granulation process was found to improve drug flowability, resulting in lower CVs for tablet and capsule characteristics, and also enhanced dissolution efficiency by increasing powder wettability. The capsules of fluconazole with Plasdone ${ }^{\circledR}$ K29/32 presented a dissolution profile of over $85 \%$ after 30 minutes, considered a satisfactory for immediate release dosage forms. Given the significant improvement in the dissolution rate for all dosage forms prepared with fluconazole granules, an associated increase in drug bioavailability is likely. 


\section{ACKNOWLEDGEMENTS}

The authors would like to extend their thanks to International Specialty Products - ISP and Colorcon do Brasil for their technical support and for supplying some equipment and materials.

\section{REFERENCES}

ALBERTINI, B.; CAVAlLARI, C.; PASSERINI, N.; GONZALES-RODRÍGUEZ, M. L.; RODRIGUEZ, L. Evaluation of B-lactose, PVP K12 and PVP K90 as excipients to prepare piroxicam granules using two granulation techniques. Eur. J. Pharm. Biopharm., v.56, n.3, p.479-487, 2003.

CHA, R.; SOBEL, J. D. Fluconazole for the treatment of candidiasis: 15 years experience. Expert. Rev. Anti. Infect. Ther., v.2, n.3, p.357-366, 2004.

FARMACOPÉIA Brasileira. 4.ed. São Paulo: Atheneu, 1988. p.V.1.1 - V.1.4.

KHAN, K. A.; RHODES, C. T. The concept of dissolution efficiency. J. Pharm. Pharmacol., v.27, n.1, p.48-49, 1975.

KOWALSKY, S. F.; DIXON, D. M. Fluconazole: a new antifungal agent. Clin. Pharm., v.10, n.3, p.179-194, 1991.

LACHMAN, L. H.; LIEBERMAN, A.; KANIG, J. In: Teoria e prática na indústria farmacêutica. Lisboa: Fundação Galouste, 2001. v.2, 899 p.

LI, Q.; RUDOLPH, V.; WEIGL, B.; EARL, A. Interparticle van der Waals force in powder flowability and compactibility. Int. J. Pharm., v.6, n.280, p.77-93, 2004.

MARTINELLO, T.; KANEKO, T. M.; VELASCO, M. V. R.; TAQUEDA, M. E. S.; CONSIGLIERI, V. O. Optimization of poorly compactable drug tablets manufactured by direct compression using the experimental mixture design. Int. $J$. Pharm., v.322, n.1-2, p.87-95, 2006.

NAIR, L.; BHARGAVA, H. N. Comparison of in vitro dissolution and permeation of fluconazole from different suppository bases. Drug Dev. Ind. Pharm., v.25, n.5, p.691694, 1999.
NOKHODCHI, A.; MAGHSOODI, M.; HASSAN-ZADEH, D.; BARZEGAR-JALALI, M. Preparation of agglomerated crystals for improving flowability and compactibility of poorly flowable and compactible drugs and excipients. Powder Technol., v.175, n.2, p.73-81, 2007.

ORELLI, J.; LEUENBERGER, H. Search for technological reasons to develop a capsule or a tablet formulation with respect with a wettability and dissolution. Int. J. Pharm., v.287, n.1-2, p.135-145, 2004.

PEREIRA, R.; FIDELIS, S.; VANUNCI, M. L.; OLIVEIRA, C. H.; MENDES, G. D.; ABIB, E.; MORENO, R. A. Bioequivalence study of two fluconazole capsule formulations in healthy volunteers. Int. J. Clin. Pharmacol. Ther,.v.42, n.1, p.39-42, 2004.

PORTA, V.; CHANG, K. H.; STORPIRTIS, S. Evaluation of the bioequivalence of capsules containing $150 \mathrm{mg}$ of fluconazole. Int. J. Pharm., v.288, n.1, p.81-86, 2005.

RICHARDSON, K.; COOPER, K.; MARRIOTT, M. S.; TARBIT, M. H.; TROKE, P. F.; WHITTLE, P. J. Discovery of fluconazole, a novel antifungal agent. Rev. Infect. Dis., v.12, supl.3, p.S267-271, 1990.

UNITED STATES PHARMACOPEIA. 31.ed. Rockville: Pharmacopeial Convention, 2008. p.19, 2412, 2745.

WAN, L. S. C.; HENG, P. W. S.; LING, B. L. Effect of polyvinyl pyrrolidone solutions containing dissolved drug on characteristics of lactose fluidized bed granules. Int. J. Pharm., v.141, n.1-2, p.161-170, 1996.

ZATLOUKAL, Z.; SKLUBALOVÁ, Z. Penetrometry and estimation of the flow rate of powder excipients. Pharmazie, v.62, n.3, p.185-189, 2007.

Received for publication on $20^{\text {th }}$ October 2008 Accepted for publication on $30^{\text {th }}$ June 2009 